\title{
Effect of hippotherapy in the global motor coordination in individuals with Down Syndrome
}

\author{
Efeito da equoterapia na coordenação motora \\ global em sujeitos com Síndrome de Down
}

\author{
Valéria Sovat de Freitas Costa ${ }^{[a] *}$, Hudday Mendes da Silva ${ }^{[b]}$, Monique de Azevêdo ${ }^{[a]}$, \\ André Ribeiro da Silva ${ }^{[c]}$, Ludmila Lucena Pereira Cabral ${ }^{[\mathrm{d}]}$, Jonatas de França Barros ${ }^{[\mathrm{d}]^{*}}$ \\ [a] Centro Universitário de Brasília (UniCEUB), Brasília, DF, Brazil \\ [b] Universidade Regional do Cariri (URCA), Crato, CE, Brazil \\ [c] Universidade de Brasília (UnB), Brasília, DF, Brazil \\ [d] Universidade Federal do Rio Grande do Norte (UFRN), Natal, RN, Brazil
}

\section{Abstract}

Introduction: Down syndrome (DS) of all genetic syndromes is the most common. In Hippotherapy, three-dimensional movements, provided by horse walking, awaken in the body of children with DS a large amount of sensory and neuromuscular stimuli, which directly interfere with overall development and the acquisition of motor skills. Objective: To analyze the effects of an Hippotherapy program on global motor coordination variables in individuals with DS of both genders and to compare individuals with the same syndrome who do not practice Hippotherapy. Methods: 41 individuals participated in the study, 20 of them practicing Hippotherapy (EG) and 21 who did not practice Hippotherapy (CG). The Körperkoordinations test für Kinder (KTK) test was used, consisting of four tasks: Balance on beams, Single-lever jump, Side-jump and Transfer on platform for analysis of motor coordination for individuals. Results: Comparing the groups,

\footnotetext{
* VSFC: MS, e-mail: valeria.sovat@uniceub.br HMS: MS, e-mail: huddaymendes@gmail.com MA: MS, e-mail: Monique.azevedo@uniceub.br ARS: MS, e-mail: andrepersonalsaude@gmail.com LLPC: MS, e-mail: ludmilalpcmartins@gmail.com JFB: PhD, e-mail: jonatas@ufrnet.br
} 
a significant difference $(\mathrm{p}<0.01)$ was observed for the Lateral Leap Motor Quotient, the EG presented a better score (114.10) than the CG (88.47), and also in the Total Motor Ratio (EG = 115.10, GC = 102.47). The individuals that practice Hippotherapy presented better results in the global motor coordination, with significant difference $(\mathrm{p}<0.05)$. In EG, $5 \%$ had high global motor coordination, $40 \%$ good and $55 \%$ normal, whereas in CG only $10 \%$ had good global motor coordination and $90 \%$ normal global motor coordination. Conclusion: It can be emphasized that equine therapy presents benefits of improvement in global motor coordination. Specifically in tasks such as the balance beam, single jump and side jump, besides global motor coordination.

Keywords: Down Syndrome. Physiotherapy. Hippotherapy.

\section{Resumo}

Introdução: A Síndrome de Down (SD), de todas as síndromes genéticas é a mais comum. Na Equoterapia, os movimentos tridimensionais, proporcionados pelo andadura do cavalo, despertam no corpo das crianças com SD uma grande quantidade de estímulos sensoriais e neuromusculares, que interferem diretamente no desenvolvimento global e na aquisição de habilidades motoras. Objetivo: Analisar os efeitos de um programa de Equoterapia sobre as variáveis de coordenação motora global em indivíduos com SD de ambos os gêneros e comparar indivíduos com a mesma síndrome que não praticam Equoterapia. Métodos: Participaram do estudo 41 indivíduos sendo 20 que praticavam Equoterapia (GE) e 21 que não praticavam Equoterapia (GC). Utilizou-se o teste Körperkoordinations test für Kinder (KTK) composto por quatro tarefas: Equilíbrio sobre traves, Salto monopedal, Salto lateral e Transferência sobre plataforma para análise de coordenação motora para indivíduos. Resultados: Comparando os grupos observou-se diferença significativa $(p<0,01)$ para o Quociente Motor da Tarefa de Salto lateral, o GE apresentando melhor escore $(114,10)$ em relação ao GC $(88,47)$, e ainda, no Quociente Motor Total (GE =115,10; GC =102,47). Os indivíduos que praticam Equoterapia apresentaram melhores resultados na coordenação motora global, com diferença significativa $(p<0,05)$. No GE, 5\% apresentaram coordenação motora global alta, 40\% boa e 55\% normal, já no GC, apenas 10\% apresentaram coordenação motora global boa e 90\% normal. Conclusão: Pode-se destacar que a equoterapia apresenta benefícios de melhora na coordenação motora global. Especificamente nas tarefas como a trave de equilíbrio, salto monopedal e salto lateral, além da coordenação motora global.

Palavras-chaves: Síndrome de Down. Fisioterapia. Equoterapia.

\section{Introduction}

Today, in the world, every minute, 18 babies arem born with a disability, which means 9.8 million babies with disabilities per year. Down Syndrome (DS), in the area of genetic syndromes, is the one with the highest incidence, with $91 \%$ of the cases [1]. In Brazil, statistics on the frequency of deficiencies, temporary or permanent, are very scarce. The United Nations [2] estimates that in developing countries the incidence is at $15 \%$ of the population, and mental retardation accounts for most of this percentage [3].

The last demographic census, conducted in 2010 by the Brazilian Institute of Geography and Statistics (IBGE) [4], included research on the existence of permanent deficiencies: visual, auditory, motor, mental / intellectual. It was identified that $45,623,910$ people, or $23.9 \%$, reported some type of disability or disability and $2,617,025$, or $1.4 \%$ of the total population, reported mental / intellectual disability. In the 2000 census, the IBGE found that about $24,600,256$ people $(14.5 \%)$ had some type of disability, with approximately 300 thousand of them with DS. This shows a significant increase in the number of people who declared some type of disability, and most of them are poor, poor, with low educational level, without information and without conditions to attend early stimulation clinics [1].

The evolution of the advance. Comparing treatment of DS has been the data available from undergoing a significant the middle of the last 
century, it is possible to perceive the increase in the life expectancy of this population [5]. Based on the studies of Moreira and Gusmão [6], DS is characterized by a variable degree of delay in mental and motor development. In the case of child development, it is observed that children with DS exhibit delay in the development of motor skills, indicating that this milestone appears at a different time when compared to children with normal development $[7,8]$.

Dysfunctions in postural control are often described in children with DS and related to difficulties such o motor coordination, problems with sensory-motor integration or simply as awkward movements, which are thus considered by Polastri and Barela [7] and Webber, Virji -Babul and Lesperance [9] when individuals are slow to adapt to the changing task and conditions of the environment or are less able to make anticipatory postural adjustments.

Studies by Coutinho [10] and Escribá [11] show that the population with DS is susceptible to a variety of musculoskeletal problems, including major neurological sequelae, leading to a considerable reduction of tasks, such as those involving slides, jumps, coordination and postural control.

According to Gorla et al. [12], global motor coordination is a fundamental component for the development of children, there is a growing interest in their role in motor control during human development, especially in periods of growth, and defines the global motor coordination the basic motor conducts, important in the acquisition of numerous abilities in the development of the people with special needs, highlighting the minimization of the difficulties in the accomplishment of the activities of daily life and acquisition of motor skills, to enable the individual with deficiency to insert himself / and to be recognized in their capacities.

As a possible solution, Hippotherapy is an interdisciplinary therapeutic and educational method, with a notable presence in the health, education and riding fields, which uses the horse, in order to stimulate the biopsychosocial development of people with disabilities or special needs $[13,14]$. Several authors affirm that the horse, used as a kinesiotherapeutic instrument in the care of people with physical disabilities, offers a motor enhancement of body alignment, to control global synergies in addition to providing a static and dynamic balance increase [15 - 20].
According to the study by Herrero et al. [21], the objectives of Hippotherapy are, among others, to improve balance, stimulate muscular strength and develop fine motor coordination. The inability to maintain the quality of posture and movement, as presented by people with DS, is reflected on the trunk, altering the harmony of the mechanics of breathing, modifying the chest and abdominal pressures. Assisted motor evolution balances the chest and abdomen, maintaining a balance between these two cavities and thus adjusting lung capacity and volumes.

However, it is still necessary to identify the kinesiotherapeutic effects of Hippotherapy in the motor coordination of subjects with Down Syndrome. With this, the present research aims to verify this effect in an Hippotherapy program in global motor coordination in subjects with DS in both genders aged between six and 14 years, when comapred with subjects with DS that did not practice Hippotherapy.

\section{Methods}

It was an observational, analytical, cross-sectional study with a population of individuals with DS, in the Federal District, between the ages of six and 14, of both genders and who practice or not. The study period was from October 2011 to March 2012. The present study was approved by the Research Ethics Committee of the Faculty of Health Sciences, University of Brasilia, according to resolutions 196/96, presenting as protocol 004/2011.

A convenience sample was used, where the researchers previously visited the institutions that worked with individuals with DS, both those who had the Hippotherapy program and those who did not. After presenting the project to those responsible for the institutions, a group of individuals eligible for this study were selected: individuals with DS, aged between seven and 13 years old, composing the study groups (Group of Equine Therapy and Control Group).

The inclusion criteria of the subjects in the research were: To present medical diagnosis of Down Syndrome; Present age between six and 14 years; submit a previous medical evaluation authorizing him to practice Hippotherapy; not make use of medication that affects the research; the individuals who practiced Hippotherapy should have performed the activity 
for at least three months; Interest in participating in the study, demonstrated by the patient and the person in charge; signing of the Informed Consent Form (ICF) by the person in charge; signature of the Term of Institutional Science by the co-participating institutions. The exclusion criteria were: To present cognitive impairment that does not understand the necessary instructions for data collection; have osteoarticular and / or neuromuscular disorders, cardiopathies or serious pulmonary diseases that prevent motor coordination tests; refusal of parents or guardians who do not agree to participate in the study; and, for the control group, had not previously practiced Hippotherapy.

The individuals with DS who performed the activity of Equoterapia were accompanied by the National Association of Equine Therapy - ANDE / BRASIL, in the city of Brasília in the Federal District and in the Cavalo Solidário Institute, based in Brasilia and in Ceilândia, which also follows the concept of treatment of ANDE / BRAZIL.

To obtain the subjects who did not practice Hippotherapy (GC), individuals were selected who attended the following philanthropic institutions of the Federal District: Association of Mothers, Parents, Friends and Exceptional Rehabilitators - AMPARE-DF and Instituto Ápice Down - Brasília.

In relation to the activities in common to the groups, it was reported based on an anamnesis form, which in the institutions related to each group, the children had physiotherapeutic followup, participated in occupational therapies, follow-up with speech therapists, Physical Education classes and besides the pedagogical accompaniment, with psychologist and physician.

They were selected, first, through the records of the institutions and annotated the telephone contacts of the parents of 45 individuals. From the contact with those responsible, the research objectives and the procedures to be carried out were oriented. The 45 agreed and their legal guardians signed the TCLE.

The motor coordination test - Koperkoordination Test furKinder (KTK) proposed by Kiphard and Schilling [22] was then applied, with the presence of a psychologist, who voluntarily participated in the research, in order to analyze whether the included individuals were comprehending the guidelines for carrying out the activities, and for those who have difficulties, how could they be guided in the best way. After this analysis, it was decided to exclude four individuals, who even after the explanations, did not understand the tasks of the test. To record KTK test data, a self-administered questionnaire was used and all subjects were evaluated by the same investigator to reduce possible procedural errors among the samples [22].

The KTK consists of a battery consisting of four items: BB- Balance Beam; LJ - Lateral Jump; MJ Monopedal Jump and TP - Transfer on platforms. The result of each item is compared with the normative values provided by the manual, being assigned a quotient to each item. The sum of the four quotients represents the motor quotient (MQ), which can be presented in percentage or absolute values, allowing to classify the children according to their level of coordinative development: (A) coordination disorders ( $\mathrm{MQ}<70$ ); (B) coordinative insufficiency $(71 \leq \mathrm{MQ} \leq 85)$; (C) normal coordination ( $86 \leq \mathrm{MQ}$ $\leq 115)$; (D) good coordination (116 $\leq \mathrm{MQ} \leq 130)$; (E) very good coordination $(131 \leq \mathrm{MQ} \leq 145)$. The KTK battery therefore allows two types of analysis of the results: (A) by test or (B) by the overall value of the MQ [12]. The tasks proposed by the KTK Test were organized in the form of circuits, as suggested by Ribeiro [23] and performed with one individual at a time.

After data collection, data on global motor coordination were tabulated to perform the statistical studies according to each objective and hypothesis. Aiming at this objective, graphs were also presented, as well as tables with descriptive measures (mean, maximum, minimum, variation and standard deviation) suitable for quantitative variables [24].

The Kolmogorov-Smirnov test was used to evaluate the normality of the data distribution. We used an inferential statistic from the Levene test to verify the homoscedasticity of the variables, evaluating the equality or non-variances between the variables of the groups. The t-test for independent samples was applied (or equivalent non-parametric test for non-normal distribution), because in the two experimental conditions the same participants were not used, as well as to verify the correlation in relation to the time of practice of equotherapy and the age and motor coordination, we chose to use the Pearson test. Descriptive analysis and statistical tests were performed in the statistical package Statistical Package for Social Sciences (SPSS 20.0), adopting the level of significance $\mathrm{p}<0.05$. 


\section{Results}

Initially, the tests were selected and applied in 41 individuals, divided into two groups: 20 individuals (11 boys and 9 girls) who practiced Hippotherapy (Experimental Group - EG), and 21 individuals (12 boys and 9 girls) (Control Group - CG).
After the normality distribution test ( $\mathrm{p}>$ 0.05 for all variables) and homoscedasticity ( $\mathrm{p}>$ 0.05 ), the test was used and it was observed that there were no significant differences between the genders (Male and Female) in all (MQ1/p $=0.29$, $\mathrm{MQ} 2 / \mathrm{p}=0.83, \mathrm{MQ} 3 / \mathrm{p}=0.59, \mathrm{MQ} 4 / \mathrm{p}=0.31$ and MQTotal $/ \mathrm{p}=0.68)$.
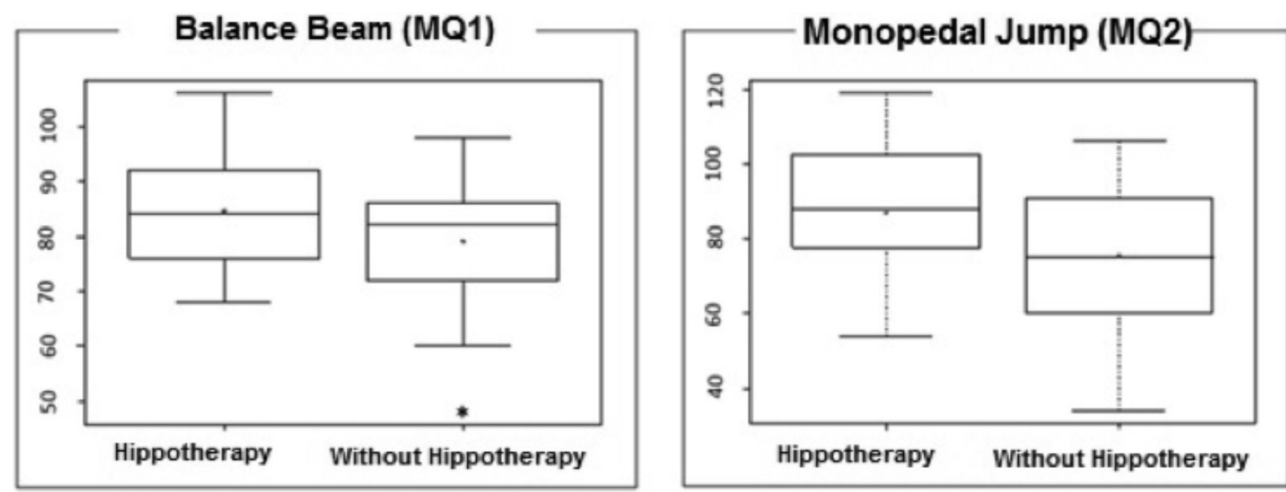

Figure 1 - Boxplot of the variables Balance Beam (MQ1) and Monopedal Jump (MQ2).

Note: MQ1 (Balance BeamTask Motor Quotient) and MQ2 (Motor Quotient of the Monopedal Jump Task) resulting from the gross score of the respective tasks. * An outlier (48) is observed for the group of individuals without Hippotherapy in the MQ1 task.

It can be seen in Figure 1 that the gross values (GV) of the variable MQ1 of EG (mean of $84.60 \pm 2.54)$, are higher when compared to the CG (mean of $80.53 \pm 2.39$ ). The MQ2 task also presented a numerical difference between the means $(87 \pm 4.13$ for $\mathrm{EG}$ and $79 \pm 4.5$ for $\mathrm{CG}$ ). However, in both cases there were no statistical differences between EG and CG ( $p=0.25$ for MQ1, and $p=0.18$ for MQ2).

In Figure 2, the results of the MQ3 and MQ4 tasks that present the average of the gross values of the EG,
$114.10 \pm 4.16$ and $88.47 \pm 4.43$, respectively, can be analyzed with the EG with higher values compared to the CG. It can also be observed that in MQ4 the maximum values, represented by the upper line of the graph, are equal in the two groups, that is, GV of 129 the minimum values in the EG is GV of 46 and of the GV CG of 55, showing that there is greater variation of the values in the EG. There was a statistical difference between EG and CG for MQ3 ( $p<0.001)$, but not for MQ4 ( $p=0.29)$.
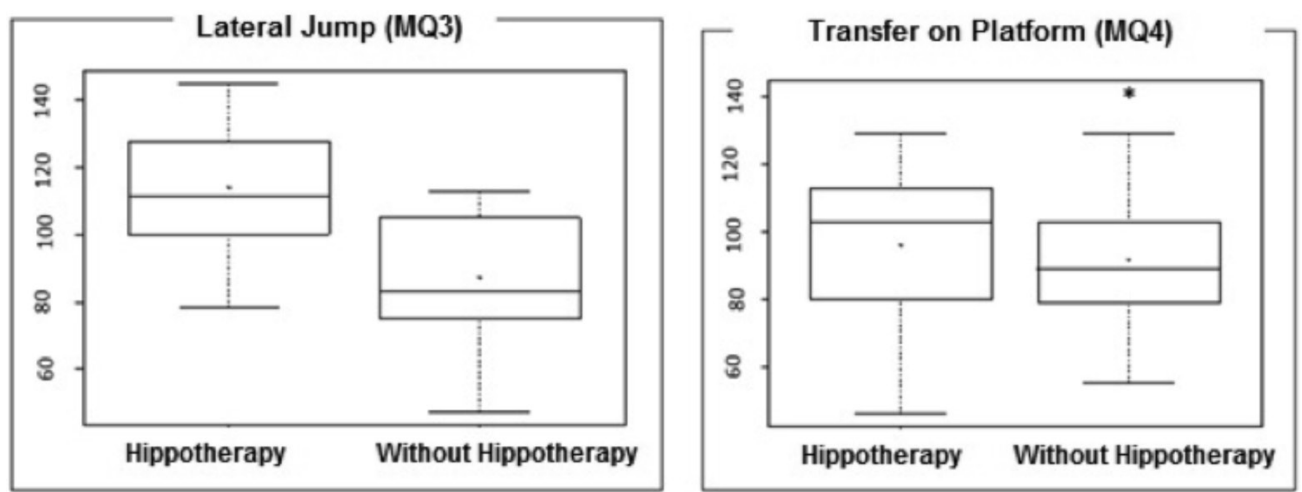

Note: MQ3 (Leading Edge Task Motor Quotient) and MQ4 (Transfer Task Motor Quotient on Platform) resulting from the gross score of the respective tasks. * An outlier (141) is observed for the group of individuals without Equoterapia in the task transfer on platform (MQ4). 
Figure 3 shows the GV result of total motor coordination. According to the averages for the Total Motor Quotient (MQT), it was observed that the EG
$(\mathrm{MQT}=115.1+2.77)$ presented means above $\mathrm{CG}$ $(\mathrm{MQT}=102.5+2.11)$ and considered significant from the $t$ test $(p<0.001)$.

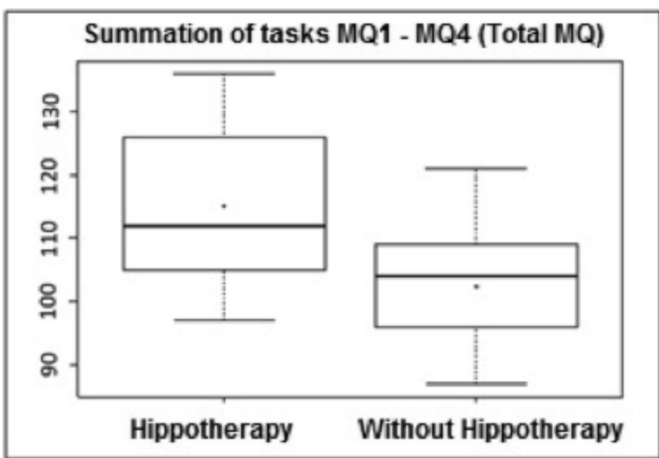

Figure 3 - Boxplot of the Summation variable MQ1 - MQ4 (Total MQ).

Note: Total MQ (Total Motor Quotient) established by the score of the sum of the motor quotients of all tasks (MQ1-MQ4).

Table 1 - T-Student test with descriptive measures of central tendency and dispersion

\begin{tabular}{|c|c|c|c|c|c|c|c|}
\hline \multirow[t]{2}{*}{ Variables } & \multirow[t]{2}{*}{ Average } & \multirow{2}{*}{$\begin{array}{l}\text { Standard } \\
\text { deviation }\end{array}$} & \multirow{2}{*}{$\begin{array}{l}\text { Average standard } \\
\text { deviation }\end{array}$} & \multirow{2}{*}{$\begin{array}{l}\text { Coeficcient } \\
\text { of variation }\end{array}$} & \multicolumn{2}{|c|}{ Confidence interval (95\%) } & \multirow[t]{2}{*}{$P$-Value } \\
\hline & & & & & Inferior & Superior & \\
\hline MQ1-EG & 84.60 & 11.34 & 2.54 & $13.40 \%$ & 79.29 & 89.91 & \multirow{2}{*}{0.25} \\
\hline$M Q 1-C G$ & 80.53 & 10.43 & 2.39 & $12.95 \%$ & 75.50 & 85.55 & \\
\hline MQ 2- EG & 87.00 & 18.47 & 4.13 & $21.23 \%$ & 78.35 & 95.65 & \multirow{2}{*}{0.18} \\
\hline$M Q 2-C G$ & 79.00 & 17.64 & 4.05 & $22.32 \%$ & 70.50 & 87.50 & \\
\hline MQ 3- EG & 114.10 & 18.59 & 4.16 & $16.29 \%$ & 105.40 & 122.80 & \multirow{2}{*}{$0.00^{*}$} \\
\hline MQ 3- CG & 88.47 & 19.30 & 4.43 & $21.81 \%$ & 79.17 & 97.77 & \\
\hline MQ 4- EG & 96.10 & 22.59 & 5.05 & $23.51 \%$ & 85.53 & 106.67 & \multirow{2}{*}{0.29} \\
\hline MQ 4- CG & 88.79 & 19.92 & 4.57 & $22.43 \%$ & 79.19 & 98.39 & \\
\hline$M Q T$ - EG & 115.10 & 15.33 & 3.43 & $16.29 \%$ & 86.93 & 101.27 & \multirow{2}{*}{$0.00^{*}$} \\
\hline MQ T - CG & 102.47 & 11.92 & 2.74 & $15.00 \%$ & 73.73 & 85.22 & \\
\hline
\end{tabular}

Note: MQ1 (Equilibrium Trave Task Motor Quotient); MQ2 (Motor Quotient of the Monopedal Jump Task); MQ3 (Motor Quotient of the Lateral Leap Task); MQ4 (Motor Transfer Quotient Transfer over Platform); MQT (Motor quotient sum of motor quotients of KTK tasks); EG - Experimental Group and CG - Control Group. * Significant values of Student's t-test $(p<0.05)$.

Table 1 shows the motor coordination results, through the KTK test, individually separating the Motor Quotient (MQ) values of each task involving the test: MQ1 - equilibrium trajectory task; MQ2 - Single-lever jump task; MQ3 - Side jump task and MQ4 - Transfer task on the platform.

In addition to the significant difference for the Total MQ variable, table 01 also shows that the MQ3 variable has a significant difference. With $\mathrm{p}$-value $<0.001$, he / she understands that the hypothesis in which the means between the control group and the experimental group are equal, are rejected. It is evident that the individuals with SD of the group that practices Hippotherapy (HG) presented better in all the tasks of the KTK test, since the motor quotient of the tasks was greater for this group, although only the task of transfer on platform and the total motor coordination showed significant difference with $\mathrm{p}<0.001$. 
The Pearson correlation coefficient was used to correlate the time that the individual with DS practices Hippotherapy with the results of global motor coordination. After applying the test, there was a strong positive correlation with significance between the duration of the equine therapy (in months) and the following variables: MQ1 $(r=0.56 / p=0.01)$, MQ2 ( $\mathrm{r}=0.53 / \mathrm{p}=0.02)$, MQ3 ( $\mathrm{r}=0.54 / \mathrm{p}=0.01)$ and MQ Total $(r=0.69 / p=0.01)$. For the MQ4, the correlation was not significant $(r=0.30, p=0.19)$.
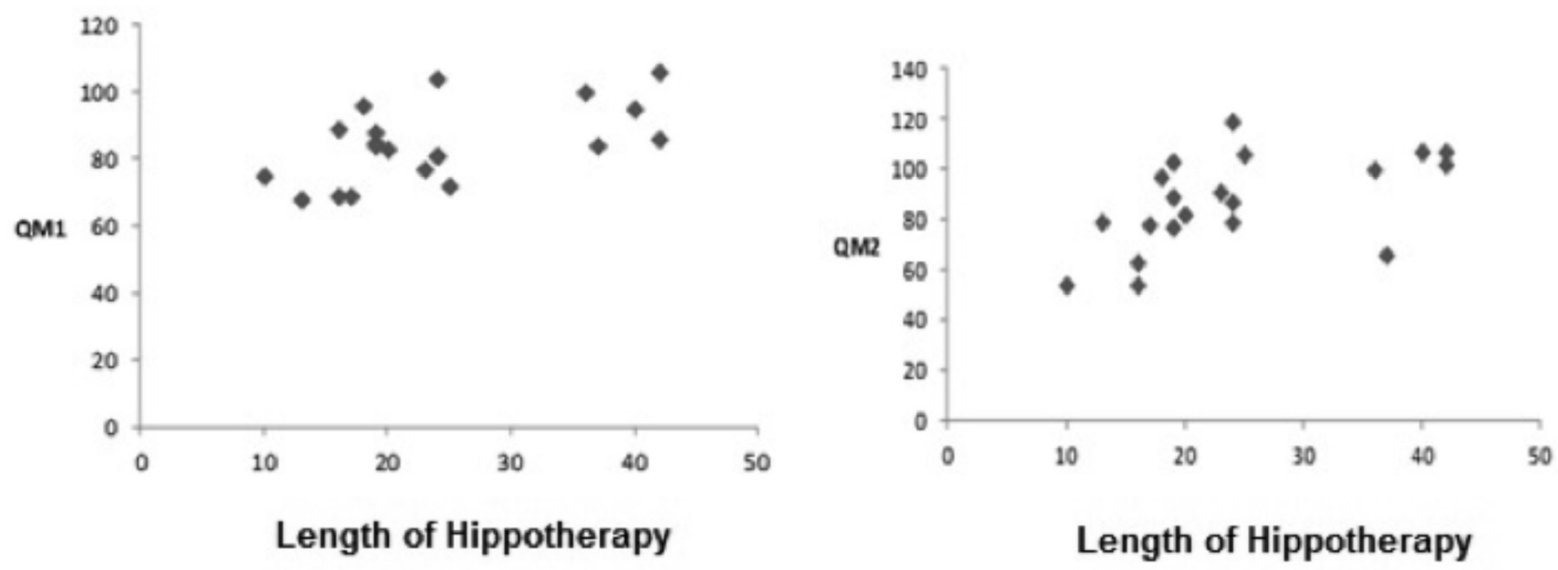

Figure 4 - Time (in months) of Hippotherapy and each Task of Koperkoordination Test furKinder (KTK) that presented significant correlation.

Figure 4 shows the correlations of the variables MQ1, MQ2, MQ3 and total MQ respectively, with the time that the individual practices Hipppotherapy. Therefore, the greater the time that Hipppotherapy performs, the greater the value of the variables in question.

The correlations with the variable age, presented inverse relationships, that is, the higher the age the lower the value of the variables under study. The following negative correlations were significant: MQ2 $(\mathrm{r}=-0.77, \mathrm{p}=0.001), \mathrm{MQ3}(\mathrm{r}=-0.63, \mathrm{p}=0.001)$, Total MQ ( $r=-0.77, p=0.001)$. For MQ1 $(r=-0.36$, $\mathrm{p}=0.12)$ and MQ4 ( $\mathrm{r}=-0.27, \mathrm{p}=0.25)$ showed no significant correlations. It was concluded that the older individuals who practice Equoterapia had the worst values in the LJ - Lateral Jump test; MJ - Monopedal Jump and total motor coordination. Figure 5 shows the correlations of the variables MQ2, MQ3 and Total MQ, respectively, with the age that the individual practices Hipppotherapy.
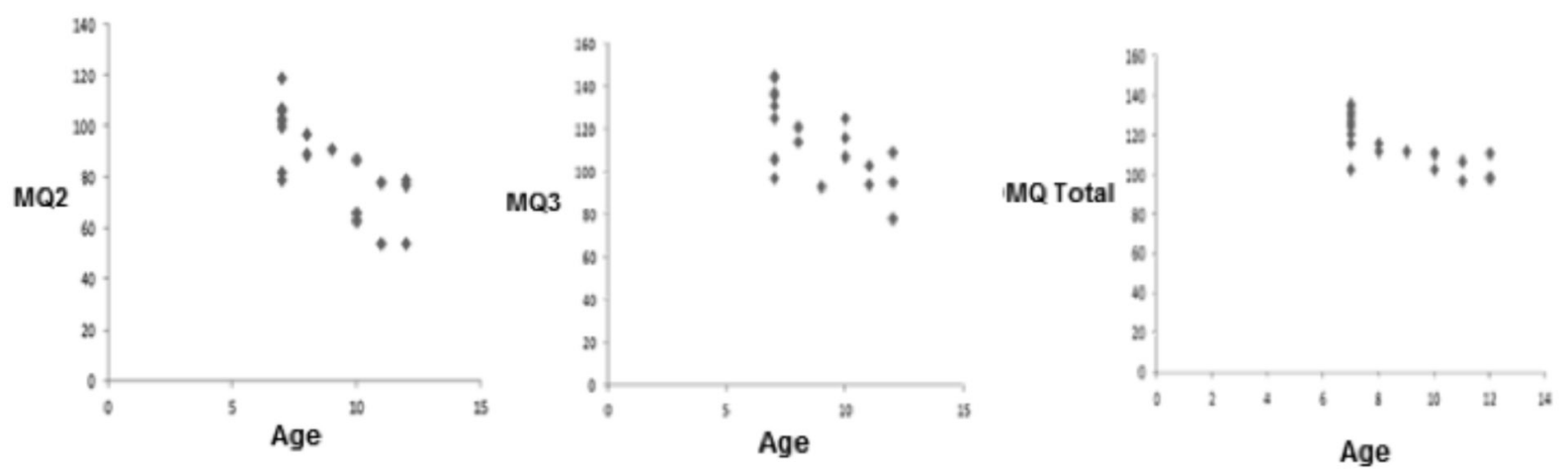

Figure 5 - Age (years) of the Experimental Group (EG) x MQ2 (Monopodal Jumping Task Motor Quotient), MQ3 (Motor Learner Task Quotient) and Total MQ (Motor Quotient Sum of motor quotients of KTK tasks). 


\section{Discussion}

It was observed, in the present study, that for both genders the mean values of the tasks performed by the Hippotherapy group were superior when compared to the individuals of the control group. These data show that individuals who practice Hippotherapy perform better in tests that involve balance, laterality, energy, strength and speed when compared to individuals with the same syndrome who do not perform Hippotherapy.

Analyzing the tasks individually, in the Balance Beam (MQ1), Santos [15] evaluated the association of Hippotherapy in the balance of individuals with DS and concluded that the subjects of Hippotherapy obtained a better result of balance in the rear compared to non-practitioners.

Likewise, Silva and Ferreira [26], also evaluating motor coordination in children with DS who participated in motor intervention using Physical Education classes, evaluated by KTK, show that in single-jumping (MQ2) and lateral jumping tasks (MQ3) the children presented progress in the development confirming with improvement of the acquired quality of the task after the intervention. Specifically for the MQ2 task, the authors found a statistically significant difference, since $78 \%$ of the children showed considerable progress. As for the MQ3 task, they show the evolution of the majority of subjects after the application of the program of activities, in relation to lateral jumps, also statistically significant results. This demonstrates that motor stimulation, whether with Hippotherapy or other modalities, promotes gain in motor coordination in children with DS.

Previous studies indicate that chromosomal diseases, especially trisomies, have a high prevalence of heart disease in all age groups [27, 28]. These statements may explain the low levels found in some KTK tasks, especially those involving jumps, in which individuals were tired quickly, since the need to jump as fast as possible.

The balance of DS patients is also altered, since the cerebellum and the vestibular apparatus, extremely important in maintaining balance and static posture, are immature in this population [29]. According to Mauerberg-Decastro [30] advocates that mental deficiency affects sensory integration, accumulating deficits of primitive reflexes appearing with changes of muscle tone or postural underadaptation, causing problems in their dynamic balance and exploration of space. Many children with Down Syndrome can not maintain their balance on just one foot for more than two seconds [31].

Varela [32], analyzing individuals with SD by KTK, showed that the younger individuals performed better in the rear balance test, as found in the present study in which the younger individuals of the EG had better results in this task. Horse movement is a favoring element of postural alignment and balance reactions, stimulating and increasing muscle contraction and postural control. Mounted on the horse, the individual receives neuromotor stimuli from the animal's back that require muscular adjustments of the trunk, promoting the control of muscular activity and maintenance of the most adequate postural alignment [33].

The present study showed that horse therapy has great influence on the variables of motor coordination and respiratory muscle strength in individuals with DS. Moreover, it also shows that the time individuals who perform Hippotherapy have a strong correlation with most of the tasks of the KTK test, having significant results for the correlation of time with the tasks of MQ1 - Balance beam task; MQ2 - Single-Skip Jump Task; MQ3 - Lateral jump task and Total MQ - Total Motor Coordination, stating that the longer the individual practices the better the results of the tasks in these tasks and the total motor coordination.

Sanches and Vasconcelos [34], in order to verify the effect of Hippotherapy in the balance and motor coordination for patients with neurological dysfunction, submitted to 18 sessions of Equoterapia (1x / week) and concluded that Hippotherapy significantly improved the balance and motor coordination.

Pereira and Leandro [35] corroborate our work, stating that they verified the benefits of Hippotherapy in the main delays of motor development with patients with DS submitted to the treatment protocol with exercises for balance, motor coordination and muscle strength. The results indicated improvements in static and dynamic balance, motor coordination and muscle strength.

Varela [32] researching individuals with DS of both sexes, separated into two groups (practitioners and non-practitioners of physical activity), using KTK for 
analysis of motor coordination, observed that female subjects practicing physical activity presented better results in all tests when compared to individuals not practicing physical activity of the same sex. In this study, no significant differences were observed in the comparison between sexes, thus showing that sex may not be a factor modulating the motor coordination gain in children with DS who practice equine therapy.

Although not significant in the present study, the male gender of the Equootherapy group presented better results in the task of balance beam (MQ1), in which the mean of the boys in this group was 87.09 and for the girls 81.5, and in the lateral jumps (MQ3) with a mean of 116.18 for boys and 111.56 for girls. These data diverge from the work of Pazin and Martins [36] who, analyzing a population with mental deficiency in motor performance tests, showed that the male gender was superior to the female, except for flexibility and balance. Like Brito [37], who analyzed the motor coordination in children with DS, evaluated the influence of capoeira practice in this population and observed superior results for males in all tests.

This study presented total MQ, representing the overall motor coordination of the EG, with results of the superior female gender, although without significant difference. Teles [38], who evaluated the effect of a motor activity program to develop motor coordination of individuals and non-DS patients, concluded that female subjects had better results in motor coordination. The same result was found by Maia [39] who carried out a research with DS patients, aiming to verify the influence on the number of weekly sessions of physical activity in the level of motor coordination. It concluded that the female population obtained better results, although without significant difference, in the majority of the coordinated capacities evaluated.

Disagreeing with this study, Collet et al. [40] analyzed the motor coordination in normal children, from eight to 14 years with the KTK method. They observed that male children presented better levels of motor coordination than female. As well as Pelozin et al. [41] in a similar study with children between nine and 11 years, with the same results. The authors also analyzed the performance or suppression of extraclass sports practice, but did not perform the association between this variable and motor coordination.
In a classification according to the values proposed by the authors of the KTK test [41], it is verified for the EG that $55 \%$ of the 11 boys had normal motor coordination and $45 \%$ had good motor coordination and, of the nine girls, $56 \%$ had normal motor coordination, 33\% had good motor coordination, and $11 \%$ had good motor coordination. In the CG, of the 12 boys, $92 \%$ had normal motor coordination and $8 \%$ had good motor coordination, with $86 \%$ showing normal motor coordination and $14 \%$ good motor coordination.

Lopes et al. [42] in a study with Portuguese children, said to be normal at 6 and 7 years of age, analyzed motor coordination and physical activity using KTK. He observed that $47.6 \%$ of the individuals had a normal motor coordination (no one had good or high coordination), which means that the majority (52.4\%) had coordinative insufficiency and coordination disorders. The authors report that these results are in line with other studies, due to the very low results of motor coordination. This fact can be explained, not by the lack of physical activity of these children (in terms of quantity), since all the children in this study did, on average, at least $60 \mathrm{~min} /$ day of physical activity; but probably because of the lack of quality of the psychomotor stimuli.

Our study, contrary to the aforementioned author, showed that seven-year-olds, the same age as the study, were the ones that presented better motor coordination of the groups. Still, the individuals of this age of EG presented better results than those of the CG, thus reinforcing the quality of the stimuli created by Hippotherapy.

It is understood that these data becomes relevant for evaluating children with DS and practice of Hippotherapyy o motor stimulus. However, it should be noted that one of the limitations of this study is that it does not present an experimental study with control of the intervening variables, such as not having the information of motor coordination before the same begin the practice of Hippotherapy, but as a comparative study of practicing groups and non-practitioners of Hippotherapy can identify significant differences leading to understand that the realization of experimental studies can present relevant results and that equine therapy should be stimulated in children with DS, promoting a greater incentive by specialized institutions such as public policies. 


\section{Conclusion}

Considering the research developed, it can be inferred that the effects of an Hippotherapy program positively influence the global motor coordination in individuals with DS, in both genders with ages between seven and 13 years, when compared to individuals with DS who do not practice Hippotherapy.

Based on the results, it was possible to verify that: i) in all KTK tests the results were better in individuals with Down Syndrome who practiced Hippotherapy than those who did not. However, only in the lateral jump task there was a significant difference $(\mathrm{p}<0.05)$; ii) the group that practiced Hippotherapy had significantly greater overall motor coordination (Total MQ) than the group that did not practice $(\mathrm{p}<0.05)$; iii) in the tasks with the balance beam, single jump and lateral jump, besides the global motor coordination, obtained a strong relation with the time of execution of Hippotherapy, that is, the longer the practice time the better the results; iv) individuals with lower age present the best results regarding global motor coordination; v) overall motor coordination in the EG was better in girls than in boys, with no statistical difference; vi) no individual in the study had any disturbance or insufficiency in the overall motor coordination, but $5 \%$ of the EG had high motor coordination, a fact that did not occur in the CG.

Although the time and number of sessions required by Hippotherapy for motor coordination responses have not yet been reported in the literature, it is concluded that the longer the activity, the better the overall motor coordination.

\section{References}

1. Projeto Down. Com sua mão, essas crianças vão longe [cited 2012 Jul 1]. Available from: https://tinyurl. com/y8777g8q.

2. Organização das Nações Unidas pela Infância (UNICEF). Projeto Belém Criança Belém/PA, 2003.

3. Fonseca V. Psicomotricidade: Perspectivas multidisciplinares. Lisboa: Editora Âncora; 2001.

4. IBGE - Instituto Brasileiro de Geografia e Estatística. Censo [cited 2012 Feb 18]. Available from: https:// tinyurl.com/y85vm3uc.
5. Berg P, Becker T, Martian A, Primrose KD, Wingen J. Motor control outcomes following Nintendo Wii use by a child with Down syndrome. Pediatr Phys Ther. 2012;24(1):78-84.

6. Moreira LMA, Gusmão FAF. Aspectos genéticos e sociais da sexualidade em pessoas com Síndrome de Down. Rev Bras Psiquiatr. 2002;24(2):94-9.

7. Polastri PF, Barela JA. Perception-Action Coupling in Infants with Down Syndrome: Effects of Experience and Pratice. Adapt Phys Act Quarterly. 2005;22(1):39-56.

8. Wang WY, Ju YH. Promoting balance and jumping skills in children with Down syndrome. Percept Mot Skills. 2002;94(2):443-8.

9. Webber A, Virji-Babul N, Edwards R, Lesperance M. Stiffiness and postural stability in adults with Down syndrome. Exp Brain Res. 2004;155(4):450-8

10. Coutinho MTPP. Intervenção precoce: estudo dos efeitos de um programa parental destinado a pais de crianças com Síndrome de Down [dissertation]. Lisboa: Universidade Técnica de Lisboa; 1999.

11. Escribá A. Propuestas de Intervención. Madrid: Gymnos; 2002.

12. Gorla JI, Araújo PF, Rodrigues JL. Avaliação motora em Educação Física adaptada: teste KTK para deficientes mentais. São Paulo: Phorte; 2009.

13. Ladislau EB, Reis JGR, Matos, UO. A Importância da Implantação da Equoterapia no Tratamento de Pessoas Portadores de Deficiências pelo Sistema de Saúde do Estado do Pará [graduate thesis]. Belém: Universidade Estadual do Pará; 2000.

14. Lima AC, Motti GS, Marciel MGG. Terapia Ocupacional e Equoterapia no Tratamento de Indivíduos Ansiosos. Multitemas. 2001(23):71-80.

15. Santos SLM. Fisioterapia na Equoterapia: Análise de seus efeitos sobre o portador de necessidades especiais. São Paulo: Ideias e Letras; 2005.

16. Lermontov T. A psicomotricidade na Equoterapia. Aparecida: Idéias e Letras; 2004.

17. Cherng RJ, Liao HF, Leung HWC, Hwang AW. The Effectiveness of Therapeutic Horseback Riding in Children with Spastic Cerebral Palsy. Adapt Phys Act Quarterly. 2004;21(2):103-21. 
18. Marcelino JFQ, Melo ZM. Equoterapia: suas repercussões nas relações familiares da criança com atraso de desenvolvimento por prematuridade. Estud Psicol (Campinas). 2006;23(3):279-87.

19. Medeiros M, Dias E. Equoterapia: bases e fundamentos. Rio de Janeiro: Revinter; 2002.

20. Sterba JA, Rogers BT, France AP, Vokes DA. Horseback riding in children with cerebral palsy: effect on gross motor function. Dev Med Child Neurol. 2002;44(5):301-8.

21. Herrero P, Asensio A, García E, Marco A, Oliván B, Ibarz A, et al. Study of the therapeutic effects of an advanced hippotherapy simulator in children with cerebral palsy: a randomised controlled trial. BMC Musculoskelet Disord. 2010;11:71.

22. Kiphard EJ, Schilling VF. Köperkoordinationstest für Kinder. Weinheim: Beltz Test GmbH; 1974.

23. Ribeiro ASC. Perfil da coordenação motora global de crianças pré-termo saudáveis acompanhadas por centros de ensino especial de Ceilândia - DF [master's thesis]. Brasília, DF: Universidade de Brasília; 2011.

24. Field A. Descobrindo a Estatística Usando o SPSS. 2nd ed. Porto Alegre: Bookman; 2009.

25. Gorla JI, Campana MB, Calegari DR. Desempenho da tarefa transferência lateral, da bateria de teste KTK, em pessoas com deficiência mental. Rev Inst Cienc Saude. 2009;27(3):206-8.

26. Silva DR, Ferreira JS. Intervenções na Educação Física em crianças com Síndrome de Down. J Phys Educ. 2001;12(1):69-76.

27. Leite DL, Miziara H, Veloso M. Malformações cardíacas congênitas em necropsias pediátricas: características, associações e prevalência. Arq Bras Cardiol. 2010;94(3):294-9.

28. Kaplan HI, Sadok B. Compêndio de psiquiatria. Porto Alegre: Artes Médicas; 1990.

29. Gimenez R, Manoel EJ. Comportamento motor e deficiência: considerações para a pesquisa e intervenção. In: Tani G. Comportamento Motor: aprendizagem e desenvolvimento. Rio de Janeiro: Guanabara Koogan; 2005. p. 314-27
30. Mauerberg-de Castro E. Atividade física adaptada. Ribeirão Preto: Tecmedd; 2005.

31. França C, Zuchetto AT. Comportamento social de portadores de Síndrome de Down em contexto de atividade motora adaptada. Revista da sociedade brasileira de atividade motora adaptada. Rev Sobama. 2004;9(1):15-24.

32. Varela P. Coordenação motora em indivíduos portadores de Síndrome de Down praticantes e não praticantes de atividade física [undergraduate thesis]. Porto, Portugal: Universidade do Porto; 2006.

33. Champagne D, Dugas C. Improving gross motor function and postural control with hippotherapy in children with Down syndrome: case reports. Physiother Theory Pract. 2010;26(8):564-71.

34. Sanches SMN, Vasconcelos LAP. Equoterapia na reabilitação da meningoencefalocele: estudo de caso. Fisioter Pesqui. 2010;17(4):358-61.

35. Pereira PA, Leandro DF. Estudo de caso: os benefícios da Equoterapia no desenvolvimento motor em uma criança portadora de Síndrome de Down. Rev Inspir Mov Saúde. 2009;1(2):20-3.

36. Pazin AC, Martins MRI. Desempenho funcional de crianças comSíndrome de Down e a qualidade de vidade seus cuidadores. Rev Neurocienc. 2007;15(4):297-303.

37. Brito AC. Capoeira, um contributo para a melhoria da coordenação motora em indivíduos com Síndrome de Down [master's thesis]. Porto, Portugal: Universidade do Porto; 2008.

38. Teles A. A influência de um programa de Atividades Motoras orientadas na expressão da coordenação motora numa população com deficiência mental [master's thesis]. Porto, Portugal: Universidade do Porto; 2004.

39. Maia LPR. Estudo dos Níveis de Aptidão Física em Indivíduos Deficientes Mentais com ou sem Síndrome de Down [master's thesis]. Porto, Portugal: Universidade do Porto; 2002. 138 p. 
40. Collet C, Folle A, Pelozin F, Botti M, Nascimento JV. Nível de coordenação motora de escolares da rede estadual da cidade de Florianópolis. Motriz Rev Educ Fís. 2008;14(4):373-80.

41. Pelozin F, Folle A, Collet C, Botti M, Nascimento JV. Nível de coordenação motora de escolares de 09 a 11 anos da rede estadual de ensino da cidade de Florianópolis/SC. Rev Mackenzie Educ Fís Esporte. 2009;8(2):123-32.
42. Lopes LO, Lopes VP, Santos R, Pereira BO. Association between physical activity and motor skills and coordination in Portuguese children. Rev Bras Cineantropom Desempenho Hum. 2011;13(1):15-21.

Received on 06/29/2016

Recebido em 29/06/2016

Approved on 09/18/2017 Aprovado em 18/09/2017 